\title{
Biochemical Characterisation of a Glucoamylase from Aspergillus niger Produced by Solid-State Fermentation
}

\author{
Christiane Trevisan Slivinski ${ }^{1}$, Alex Vinicius Lopes Machado ${ }^{1}$, Jorge Iulek $^{2}$, Ricardo \\ Antônio Ayub $^{3}$ and Mareci Mendes de Almeida ${ }^{1^{*}}$ \\ ${ }^{I}$ Departamento de Engenharia de Alimentos; Centro de Ciência e Tecnologia de Alimentos; Universidade Estadual \\ de Ponta Grossa; Ponta Grossa - PR - Brasil. ${ }^{2}$ Departamento de Química; Centro de Biotecnologia; Universidade \\ Estadual de Ponta Grossa; Ponta Grossa - PR - Brasil. ${ }^{3}$ Departamento de Fitotecnia e Fitossanidade; Centro de \\ Biotecnologia; Universidade Estadual de Ponta Grossa; Av. Gal. Carlos Cavalcanti, 4748; 84030-000; Ponta \\ Grossa - PR - Brasil
}

\begin{abstract}
In this work, glucoamylase was produced by Aspergillus niger in solid-state fermentation. The enzyme was partially purified by ammonium sulphate precipitation and ion exchange and gel filtration chromatographies. Its molecular mass was estimated as $118.17 \mathrm{kDa}$ by electrophoresis. The partially purified enzyme had an optimum pH range of 4.5-5.0 and an optimum temperature of $60^{\circ} \mathrm{C}$, with average activity $152.85 \mathrm{U} \mathrm{mL}^{-1}$. Thermal and pH stability assays with the crude extract showed that more than $60 \%$ of the activity remained at $\mathrm{pH} 4.6$ and $60{ }^{\circ} \mathrm{C}$, even after an exposition to these conditions longer than $24 \mathrm{~h}$. Yet, after purification, the enzyme was stable at these for at least 4 $h$, which indicated that its purification for use in starch saccharification was inadvisable. $K_{M}$ and $V_{\max }$ were $0.34 \mathrm{mg}$ $m L^{-1}$ and $160.22 U \mathrm{~mL}^{-1}$, respectively.
\end{abstract}

Key words: glucoamylase, Aspergillus niger, solid-state fermentation, biochemical characterization, purification

\section{INTRODUCTION}

Fermentation processes can be accomplished by bacteria, fungi or yeast, and the choices depend upon the desired product. For enzyme production, there is a preference towards the usage of filamentous fungi because they present a better capability to secret high protein levels in the culture media (Gouka et al., 1997), either solid or submerged (Koutinas et al., 2003). A suitable substrate determination is extremely important for the process feasibility and the substrate must be cheap (Couto and Sanromán, 2006).
The amylolytic enzymes play an important role in the food industry and many industrial processes involving starch require these enzymes for the hydrolysis. The hydrolysis occurs at high temperatures and involves two steps, liquefaction and saccharification, for which the $\mathrm{pH}$ and the temperature must be well determined to avoid the undesirable by-products (Buchholz and Seibel, 2008).

Glucoamylase (E.C. 3.2.1.3) is an amylolytic enzyme capable to hydrolyze $\beta$-D-glucose units on non-reducing ends of starch molecules. It can also lyse $\alpha-1,6$ bonds on amylopectin branching points,

*Author for correspondence: mareci@uepg.br 
thus promoting an almost complete starch hydrolysis into glucose (Selvakumar et al., 1996). Its main application is on the production of syrups with 96-98\% of glucose (Aiyer, 2005; GuzmánMaldonado and Paredes-Lópes, 1995). The glucoamylase is added to the starch paste at the saccharifying step when it is around $60{ }^{\circ} \mathrm{C}$, thus the enzyme must be stable at this temperature for a long time. The hydrolyzates can be used as carbon source in fermentations; in other cases, they can be part of the final product, such as in soft drinks, icecreams, sauces, tinned fruits, breads, etc. (Aiyer, 2005). Most of the industrially used glucoamylases are produced by Aspergillus and Rhizopus genus lineages; the one from the former is the most thermostable (Norouzian et al., 2006).

The goals of this work were to partially purify and to characterize biochemically the glucoamylase from Aspergillus niger produced in solidstatefermentation using a potato processing residue as substrate.

\section{MATERIALS AND METHODS}

\section{Microorganisms}

A culture of Aspergillus niger NRRL 330 lineage grown in acidified potato dextrose agar (PDA) and stored at $4{ }^{\circ} \mathrm{C}$ was used in this work.

\section{Culture medium, inoculum preparation and fermentation conditions}

Potato processing residue was used as the substrate for the fungus growth; $50 \mathrm{~g}$, without any supplementation, were poured into $250 \mathrm{~mL}$ Erlenmeyer flasks, the humidity was adjusted to $85 \%(w / w)$ and then autoclaved at $121{ }^{\circ} \mathrm{C}$ for $15 \mathrm{~min}$. Analyses of the medium thus prepared showed that it contained, in $\mathrm{g} 100 \mathrm{~mL}^{-1}$ : starch, 12.56; reducing sugars, 0.21 ; glucose, 0.00 .; proteins, 1.30; lipids, 0.04; fibers, 0.43; ashes, 0.56; phosphorous, 0.02; nitrogen, 0.21 , at $\mathrm{pH} 5.1$. One mililiter of spore suspension at $10^{7} \mathrm{ufc} \mathrm{mL}^{-1}$ (Spier et al., 2006) was added to each flask and then fermented at $32{ }^{\circ} \mathrm{C}$ for $48 \mathrm{~h}$ without stirring. After fermentation, $25 \mathrm{~mL}$ of acetate buffer $\left(0.1 \mathrm{~mol} \mathrm{~L}^{-1}, \mathrm{pH}\right.$ 4.6) was added to each flask, followed by trituration with a glass rod. The flasks were then stirred in a shaker (New Brunswick Scientific, Edison, NJ - USA, C25KC) at $150 \mathrm{rpm}$ and $15{ }^{\circ} \mathrm{C}$ for $1 \mathrm{~h}$, followed by centrifugation at $12,500 \times \mathrm{g}$ and $4^{\circ} \mathrm{C}$ for $15 \mathrm{~min}$ (Himac CR21G,
Hitachi Koki, Tokyo, Japan). Finally, the supernatant, hereafter considered the crude extract, was filtered through paper (Whatman $\mathrm{n}^{\circ} 1$ ) and stored at $4{ }^{\circ} \mathrm{C}$.

\section{Enzymatic assay}

The method described by Silva et al. (2005) was adapted to give a final volume of $1 \mathrm{~mL}$, which contained the enzyme solution $(200 \mu \mathrm{L})$, soluble starch at $5 \mathrm{mg} \mathrm{mL}^{-1}(333 \mu \mathrm{L})$ and acetate buffer $\left(0.1 \mathrm{~mol} \mathrm{~L}^{-1}, \mathrm{pH} 4.6\right)(467 \mu \mathrm{L})$. The reaction was carried out for $15 \mathrm{~min}$ at $60{ }^{\circ} \mathrm{C}$ and then was inactivated by heating at $100{ }^{\circ} \mathrm{C}$ for $5 \mathrm{~min}$. The control contained $200 \mu \mathrm{L}$ of the enzyme solution and $800 \mu \mathrm{L}$ of the same acetate buffer. Both enzyme produced and free glucose as in the control were quantified by the glucose oxidase method (Dahlqvist, 1961). One glucoamylase unit corresponded to the amount of enzyme that catalysed the formation of $1.0 \mu \mathrm{mol}$ of glucose per minute under the assay conditions.

\section{Kinetic studies of the glucoamylase production}

The fungus growth was carried out for $120 \mathrm{~h}$ at $32{ }^{\circ} \mathrm{C}$ under the previously described conditions. Two sets of flasks, comprising 11 flasks each were used for fermentation and samples as whole flask were withdrawn at each $12 \mathrm{~h}$.

\section{Partial purification of glucoamylase}

The precipitated fraction at $60-85 \%$ ammonium sulphate saturation of the crude extract at $4{ }^{\circ} \mathrm{C}$ was centrifuged at $12,500 \times \mathrm{g}$ for $30 \mathrm{~min}$, re-dissolved in acetate buffer $\left(0.1 \mathrm{~mol} \mathrm{~L}^{-1}, \mathrm{pH} 4.6\right)$ and dialyzed against phosphate buffer $\left(5 \mathrm{mmol} \mathrm{L}{ }^{-1}, \mathrm{pH} 6.9\right)$. The sample was loaded into a column (C16/20, $16.0 \mathrm{~mm}$ diameter and $16.0 \mathrm{~cm}$ height - GE Healthcare) with anionic exchange resin (Q-Sepharose Big Beads Coarse - GE Healthcare); $4.0 \mathrm{~mL}$ fractions were collected at a $60 \mathrm{~mL} \mathrm{~h}^{-1}$ flow, using as eluents, in the sequence, phosphate buffer 5, 20 and $200 \mathrm{mmol} \mathrm{L}^{-1}(\mathrm{pH}$ 6.9), then a $0.0-1.0 \mathrm{~mol} \mathrm{~L}^{-1} \mathrm{NaCl}$ gradient followed by elutions with constant $\mathrm{NaCl}$ concentrations at 1,2 and $3 \mathrm{~mol} \mathrm{~L} \mathrm{~L}^{-1}$, all $\mathrm{NaCl}$ solutions in phosphate buffer (200 mmol L-1, $\mathrm{pH}$ 6.9). These samples were read at $280 \mathrm{~nm}$ for each fraction.

The fractions with glucoamylase activity were pooled, dialyzed against acetate buffer at $5 \mathrm{mmol} \mathrm{L}{ }^{-1},(\mathrm{pH} 4.6)$, and loaded into a column (C16/20, $16 \mathrm{~mm}$ diameter and $16.0 \mathrm{~cm}$ height - GE Healthcare) with cationic exchange resin 
(SP-Sepharose Fast Flow - GE Healthcare); $4.0 \mathrm{~mL}$ fractions were collected at a $60 \mathrm{~mL} \mathrm{~h}^{-1}$ flow, using as eluents, in the sequence, acetate buffer 5, 20 and $200 \mathrm{mmol} \mathrm{\textrm {L } ^ { - 1 }}(\mathrm{pH} 4.6)$, then a $0.0-2.0 \mathrm{~mol} \mathrm{~L}^{-1} \mathrm{NaCl}$ gradient (in the last buffer). Finally, the fractions with glucoamylase activity were pooled, dialyzed and loaded into a column (17 $\mathrm{mm}$ diameter and $78.5 \mathrm{~cm}$ height) with gel filtration resin (Sephadex G-100 - Sigma-Aldrich); $4.0 \mathrm{~mL}$ fractions were collected at a $8 \mathrm{~mL} \mathrm{~h}^{-1}$ flow, using acetate buffer $\left(5 \mathrm{mmol} \mathrm{L}^{-1}, \mathrm{pH} 4.6\right)$ as eluent. The absorbance of each fraction was read at $280 \mathrm{~nm}$.

During all purification steps, the presence of glucoamylase and its specific activity were monitored with enzymatic assays, SDS-PAGE electrophoreses at $10 \%$ (Laemmli, 1970) and protein content assays (Lowry, 1951) using bovine serum albumin as standard.

\section{Determination of the optimum temperature and} pH for the partially purified glucoamylase

A $2^{\mathrm{k}}$ complete factorial design with the center point and the axial (star) points was used to determine the optimum temperature and $\mathrm{pH}$. The response variable was the glucoamylase activity, measured as described previously (Table 2 ). The results were evaluated with the Experimental Design modulus using the software Statistica for Windows, version 5.0 (StatSoft, Inc., Chicago-IL).

Effect of the temperature and $\mathrm{pH}$ on the glucoamylase stability

These assays were carried out for both the crude extract and the partially purified enzyme. The $\mathrm{pH}$ stability was assayed at 3.6, 4.0, 4.6 and 5.0 with acetate buffer $\left(0.1 \mathrm{~mol} \mathrm{~L}^{-1}\right)$ and at 6.0 and 7.0 with phosphate buffer $\left(0.1 \mathrm{~mol} \mathrm{~L}^{-1}\right)$. In each assay, $0.5 \mathrm{~mL}$ of the sample was diluted with $19.5 \mathrm{~mL}$ of the above-cited buffers and incubated at $60{ }^{\circ} \mathrm{C}$. The experiment was carried out for $24 \mathrm{~h}$. A $1 \mathrm{~mL}$ aliquot was withdrawn after $0,2,4,8$ and $24 \mathrm{~h}$. The aliquots were diluted in $30 \mathrm{~mL}$ of acetate

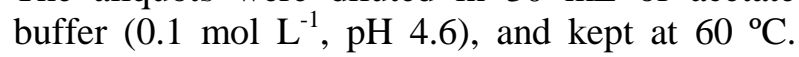
Then, the residual activity was measured.

The glucoamylase thermostability was assayed at $15,35,60$ and $70{ }^{\circ} \mathrm{C}$. In each assay, $0.5 \mathrm{~mL}$ of the sample was diluted with $19.5 \mathrm{~mL}$ of acetate buffer (0.1 mol L $\left.\mathrm{L}^{-1}, \mathrm{pH} 4.6\right)$. The experiment was carried out for $24 \mathrm{~h}$; a $1 \mathrm{~mL}$ aliquot was withdrawn after $0,2,4,8$ and $24 \mathrm{~h}$. The aliquots were cooled in ice bath and then the residual activity was measured at $60{ }^{\circ} \mathrm{C}$ and $\mathrm{pH}$ 4.6.

\section{Determination of the kinetic parameters $\left(K_{M} \mathrm{e}\right.$ $V_{\max }$ )}

The enzymatic assay was carried out with starch solution in the concentration range $1-10 \mathrm{mg} \mathrm{mL}^{-1}$, sampled at $1 \mathrm{mg} \mathrm{mL}^{-1}$ steps, $\mathrm{pH} 4.6$, acetate buffer $\left(0.1 \mathrm{~mol} \mathrm{~L}^{-1}\right)$ and $60{ }^{\circ} \mathrm{C}$ as described above. The $K_{M}$ and $V_{\max }$ values were calculated from a HanesWoolf plot (Hanes, 1932).

\section{RESULTS AND DISCUSSION}

\section{Kinetic study of glucoamylase production}

Figure 1 shows the glucoamylase activity and the free glucose concentration during the enzyme production.

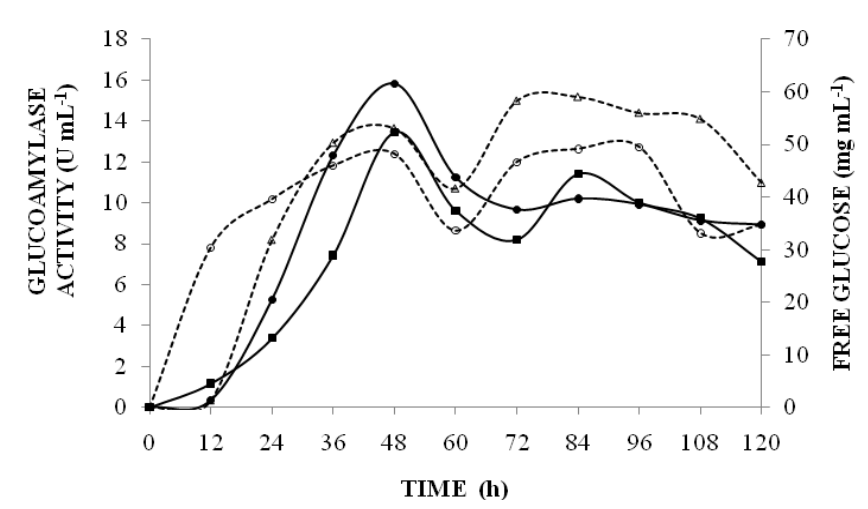

Figure 1 - Evolution of the glucoamylase activity and the free glucose concentration during the assay. (continuous lines: glucoamylase activity $1, \bullet$ glucoamylase activity 2 ; hatched lines: $\square$ free glucose 1 , $\circ$ free glucose 2). 
Evidently A. niger was capable to produce glucoamylase in solid-state fermentation using a potato processing residue as substrate and the best yield was after $48 \mathrm{~h}\left(13.46 \mathrm{U} \mathrm{mL}^{-1}\right.$ for assay number 1 and $15.82 \mathrm{U} \mathrm{mL}^{-1}$ for assay number 2 ). In the beginning as the enzyme was produced, the free glucose concentration grew up to $48 \mathrm{~h}$ and then its concentration as well as the glucoamylase activity started to fall. The enzyme production by the microorganism is repressed due to the glucose high concentration (Rajoka and Yasmeen, 2005) known as "glucose repression", which involves complex interactions between DNA binding repressors, their cognate elements and components of the transcriptional machinery in yeast (Griggs and Johnston, 1991; Keleher et al., 1992; Hu et al., 1995; Treitel and Carlson, 1995; De Vit et al., 1997; Park et al., 1999). Nevertheless, when the glucose concentration decreases, the microorganism starts to produce glucoamylase again and then to hydrolyze the starch to produce more glucose. This modulation (initial repression and subsequent desrepression) was also observed for Saccharomyces diastaticus (Kim et al., 2004).

\section{Partial purification of glucoamylse}

Ammonium sulphate precipitation was the first step of the purification procedure; the fraction precipitated in the saturation range $60-85 \%$ was the one with most of the glucoamylase activity and therefore loaded onto the Q-Sepharose column after re-dissolving and dialysis. Figure 2a showed the corresponding chromatographic profile in which peaks were identified from $A$ to $G$. Fractions from all the peaks were assayed, but only $\mathrm{n}^{\circ} 80-85$, which were included in pool $\mathrm{D}$, eluted during the gradient in which phosphate buffer was kept constant at $200 \mathrm{mmol} \mathrm{L}^{-1},(\mathrm{pH}$ $6.9)$, with the $\mathrm{NaCl}$ concentration changing from 0.0 to $1.0 \mathrm{~mol} \mathrm{~L}^{-1}$, had glucoamylase activity. This pool, after new dialysis, was then loaded onto the SP-Sepharose column (Fig. 2b). Two peaks, D-I and D-II, were obtained and the corresponding fractions were assayed. Only the fractions 4-9 (peak/pool D-I) had significant glucoamylase activity and was then further loaded onto the sephadex G-100 column. This resulted five peaks, D-I-1, D-I-2, D-I-3, D-I-4 and D-I-5, (Fig. 2c), but only fractions 27-30 (peak/pool D-I-4) had glucoamylase activity.

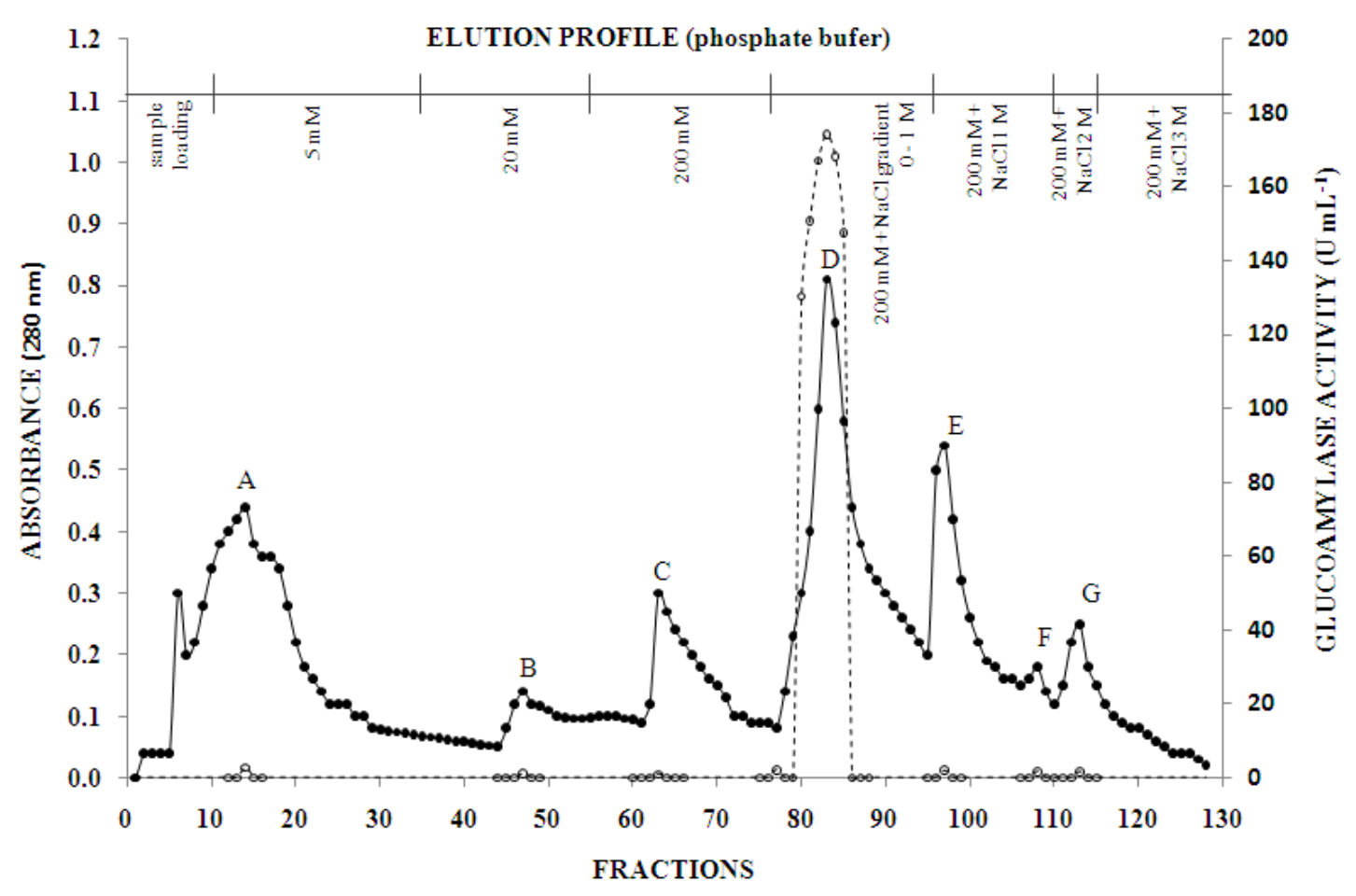

Figure 2a - Q-Sepharose chromatography profile. (•) absorbance in $280 \mathrm{~nm}$; (०) glucoamylase activity, determined for relevant fractions. 


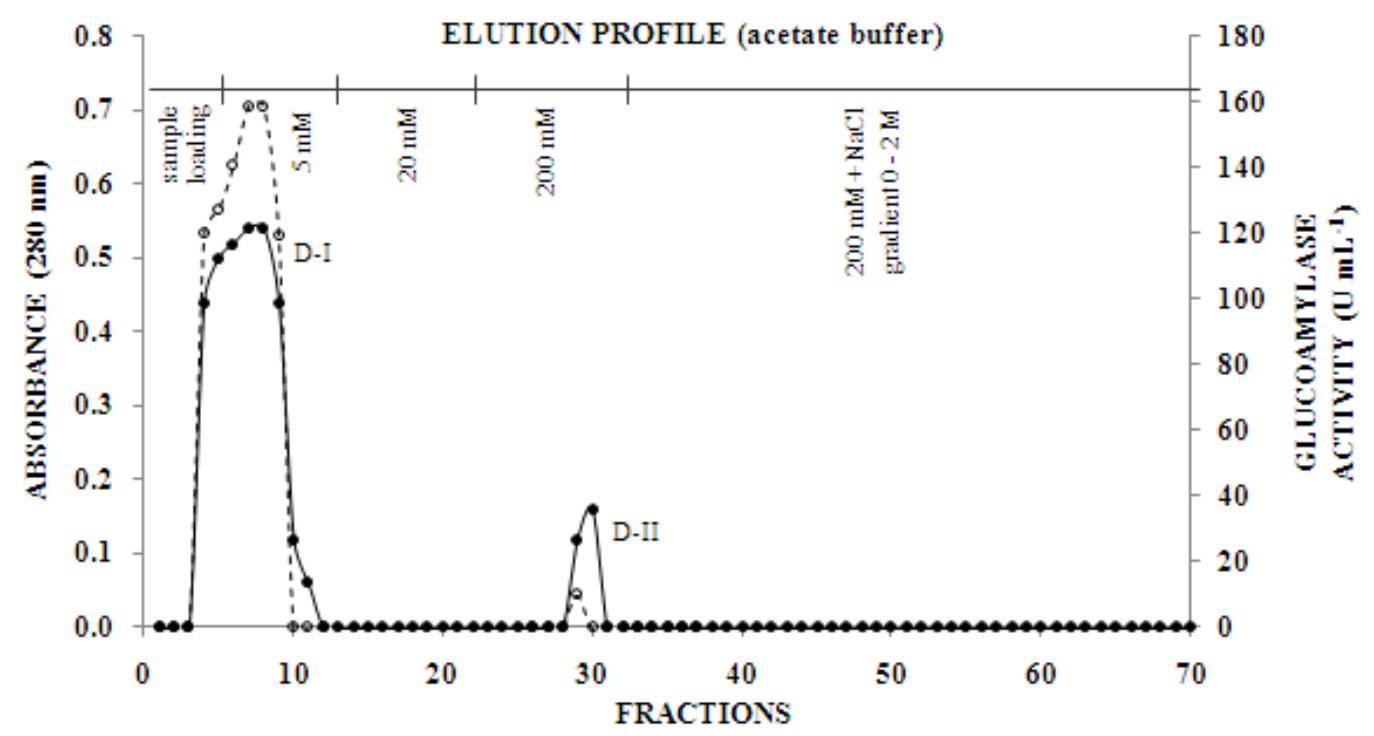

Figure 2b - SP-Sepharose chromatography profile. (•) absorbance in $280 \mathrm{~nm}$; (०) glucoamylase activity, determined for relevant fractions.

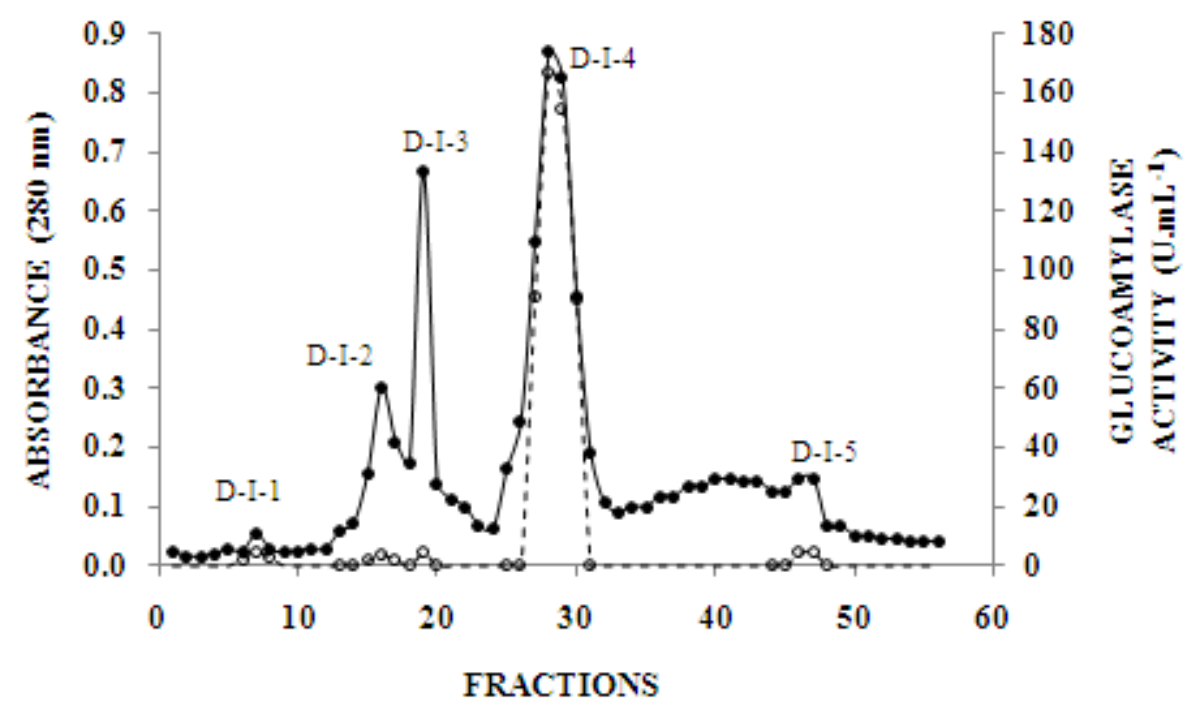

Figure 2c - Sephadex G-100 chromatography profile. (•) absorbance in $280 \mathrm{~nm}$; (०) glucoamylase activity, determined for relevant fractions.

Table 1 summarizes the results from each purification step. The enzyme purity increased 109.23-folds with a $11.71 \%$ yield and a final specific activity of $2174.72 \mathrm{U} \mathrm{mg}^{-1}$.

The partial purification was confirmed by SDSPAGE electrophoresis (Fig. 3). The presumed glucoamylase band corresponded to a molecular mass of $118.17 \mathrm{kDa}$ calculated by linear regression, which was in good agreement with the $112 \mathrm{kDa}$ value found by the same technique for glucoamylase II (Pazur and Kleppe, 1971). 
Table 1 Purification factor and \% of glucoamylase activity recovery.

\begin{tabular}{lcccccccc}
\hline \multicolumn{1}{c}{ Step } & $\begin{array}{c}\text { Volume } \\
(\mathrm{mL})\end{array}$ & $\begin{array}{c}\text { Activity } \\
\left(\mathrm{U} \mathrm{mL}^{-1}\right)\end{array}$ & $\begin{array}{c}\text { Total } \\
\text { Activity }(\mathrm{U})\end{array}$ & $\begin{array}{c}\text { Total Protein } \\
\text { Concentration } \\
\left(\mathrm{mg} \mathrm{mL}^{-1}\right)\end{array}$ & $\begin{array}{c}\text { Total } \\
\text { Protein } \\
\text { Mass }(\mathrm{mg})\end{array}$ & $\begin{array}{c}\text { Specific } \\
\text { Activity } \\
\left(\mathrm{U} \mathrm{mg}^{-1}\right)\end{array}$ & $\begin{array}{c}\text { Purification } \\
\text { Factor }\end{array}$ & \% Recovery \\
\hline Raw extract & 1470 & 10.61 & 15596.70 & 0.533 & 783.29 & 19.91 & 1.00 & 100 \\
60-85\% p & 41 & 103.66 & 4250.06 & 0.258 & 10.58 & 401.70 & 20.17 & 27.24 \\
pool D & 20 & 174.20 & 3484.00 & 0.132 & 2.64 & 1319.69 & 66.28 & 22.33 \\
pool D-I & 20 & 159.07 & 3199.40 & 0.119 & 2.38 & 1344.28 & 67.54 & 20.51 \\
pool D-I-4 & 11 & 166.97 & 1826.77 & 0.077 & 0.84 & 2174.72 & 109.23 & 11.71 \\
\hline
\end{tabular}

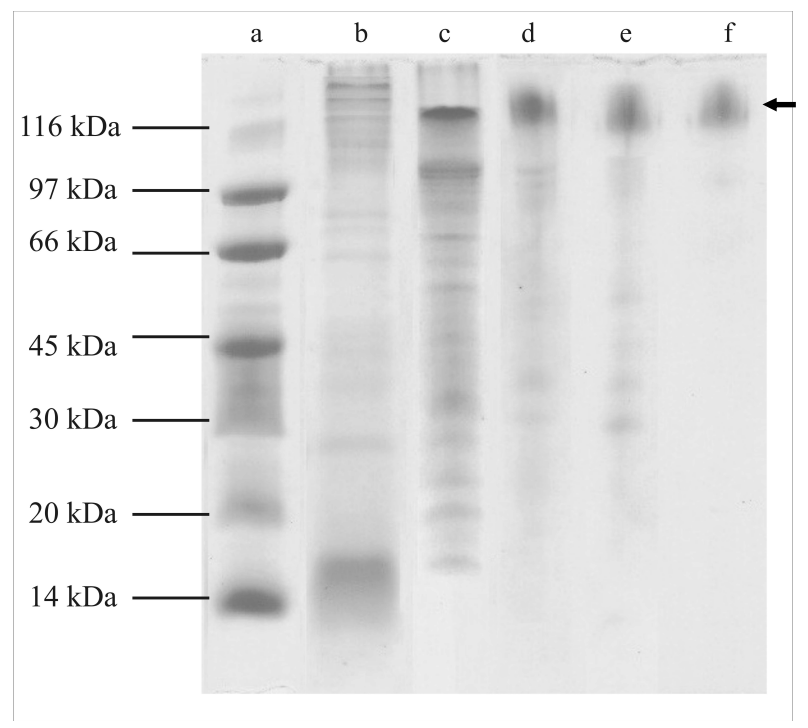

Figure 3 - SDS-PAGE electrophoretic profile including relevant samples from all purification steps. The lanes were loaded with: A) molecular mass markers (116 kDa 2- $\beta$ galactosidase; $97 \mathrm{kDa}$, phosphorylase b; $66 \mathrm{kDa}$, albumin; $45 \mathrm{kDa}$, ovalbumin; 30 $\mathrm{kDa}$, carbonic anhydrase; 20,1 kDa, trypsin inhibitor and 14,4 kDa, $\alpha$-lactalbumin); B) crude extract; C) ammonium sulphate $60-85 \%$ saturation precipitate; D) pool D; E) pool D-I and F) pool D-I-4. On lane F, an arrow indicates the presumed glucoamylase band.

\section{Optimum pH and temperature determination}

Tables 2 and 3 show the assay results. The dependent variable values were coded and the response variable was the enzyme activity. Both $\mathrm{pH}$ and temperature variables, as well as their interaction, were significant at $\mathrm{p}<0.05$.

As observed in Table 3, both variables were significant, with a higher effect from the $\mathrm{pH}$. At increasing the level from -1 to +1 , the $\mathrm{pH}$ effect was negative, while the temperature effect was positive. Concerning the interaction, the effect was negative, implying that the set $\mathrm{pH} 3.6$ and temperature $46{ }^{\circ} \mathrm{C}$ had a higher effect than any of these isolated variables.
The results in Table 4 showed that the model was predictive and statistically significant, with Fcal/Ftab equal to 54.21, p $<0.05$. The mathematical model derived from the statistical analysis is presented in the equation below, which gives $\mathrm{R}^{2}=0.9964$ for the experimental data, where $\hat{Y}$ represents the number of glucoamylase activity units, $\mathrm{X}_{1}$ represents the numerical value of the $\mathrm{pH}$ and $\mathrm{X}_{2}$ represents the numerical value of the temperature $\left({ }^{\circ} \mathrm{C}\right)$ :

$$
\begin{gathered}
\hat{Y}=138,837-35,865 \mathrm{X}_{1}-39,315 \mathrm{X}_{1}^{2}+8,306 \mathrm{X}_{2}- \\
40,191 \mathrm{X}_{2}^{2}-20,312 \mathrm{X}_{1} \mathrm{X}_{2}
\end{gathered}
$$


Table 2 - Factorial design matrix, factors temperature and $\mathrm{pH}, 2^{\mathrm{k}}$ with center point (triplicate) and axial (star) points. The response is the glucoamylase activity.

\begin{tabular}{cccccc}
\hline & $\mathbf{p H}$ & $\mathbf{p H}$ & $\boldsymbol{T}\left({ }^{\mathbf{0}} \mathbf{C}\right)$ & $\boldsymbol{T}\left({ }^{\mathbf{0}} \mathbf{C}\right)$ & $\begin{array}{c}\text { Activity } \\
\left(\mathbf{U} \mathbf{~ m L}^{-1}\right)\end{array}$ \\
\hline 1 & -1 & -1 & 3.6 & 46 & 70.33 \\
2 & +1 & -1 & 6.9 & 46 & 32.83 \\
3 & -1 & +1 & 3.6 & 71 & 128.76 \\
4 & +1 & +1 & 6.9 & 71 & 10.01 \\
5 & +1.41 & 0 & 7.5 & 60 & 13.48 \\
6 & -1.41 & 0 & 3.0 & 60 & 105.55 \\
7 & 0 & 1.41 & 5.0 & 75 & 68.64 \\
8 & 0 & -1.41 & 5.0 & 40 & 46.91 \\
9 & 0 & 0 & 5.0 & 60 & 138.98 \\
10 & 0 & 0 & 5.0 & 60 & 138.88 \\
11 & 0 & 0 & 5.0 & 60 & 138.68 \\
\hline
\end{tabular}

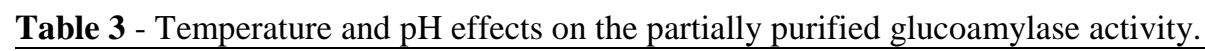

\begin{tabular}{ccccc}
\hline & Effects & Pure error & t(2) & p \\
\hline Mean & 138.837 & 0.0881 & 1574.288 & 0.000000 \\
(1) pH (L) & -71.7306 & 0.1081 & -663.107 & 0.000002 \\
(2) Temperature (L) & 16.6117 & 0.1081 & 153.566 & 0.000042 \\
(1) e (2) & -40.6250 & 0.1527 & -265.953 & 0.000014 \\
\hline
\end{tabular}

Table 4 - Variance analysis (ANOVA) to determine the optimal $\mathrm{pH}$ and temperature.

\begin{tabular}{lcccccc}
\hline & $\begin{array}{c}\text { Quadratic } \\
\text { Sum }\end{array}$ & $\begin{array}{c}\text { Degrees of } \\
\text { Freedom }\end{array}$ & $\begin{array}{c}\text { Quadratic } \\
\text { Average }\end{array}$ & Fcal & Ftab & Fcal/Ftab \\
\hline Regression & 26174.11 & 5 & 5234.82 & 273.78 & 5.05 & 54.21 \\
Residue & 95.61 & 5 & 19.12 & & & \\
Lack of fit & 95.56 & 3 & 31.85 & & & \\
Pure error & 0.05 & 2 & 0.02 & & \\
Total & 26269.72 & 10 & & &
\end{tabular}

Effect of temperature and $\mathrm{pH}$ on the stability of glucoamylase

For the crude extract, the stability $\mathrm{pH}$ and temperature stability range were 4.0-5.0 and $35-60{ }^{\circ} \mathrm{C}$, respectively, with $72.87 \%$ activity at $\mathrm{pH} 4.6$ and $60.33 \%$ activity at $60{ }^{\circ} \mathrm{C}$, when exposed for more than $24 \mathrm{~h}$ (Figures $4 \mathrm{a}$ and $4 \mathrm{c}$ ).
This showed that the enzyme was thermostable with a good action in acidic $\mathrm{pH}$. For the partially purified enzyme, a reasonable amount of activity remained up to $4 \mathrm{~h}$ at $\mathrm{pH} 6.0$ and $60{ }^{\circ} \mathrm{C}$, but after 8 h only $25 \%$ activity remained (Figures $4 \mathrm{~b}$ and $4 d$ ), an unfavourable fact for an industrial application of the purified enzyme.

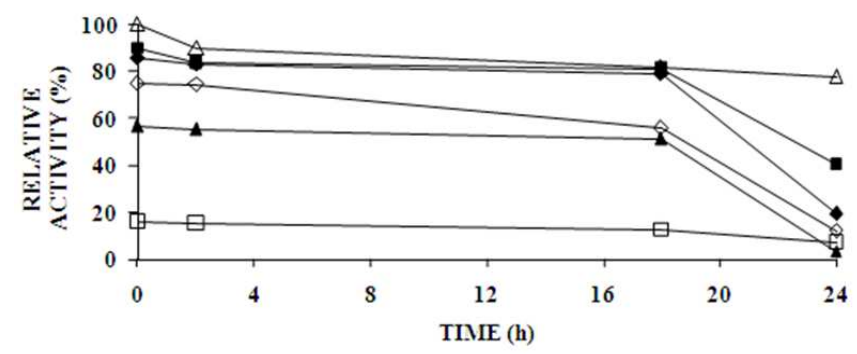

Figure 4a - Stability of glucoamylase (crude extract) with respect to the $\mathrm{pH}: \Delta 3.6,4.0, \Delta 4.6$, $5.0, \diamond 6.0, \square 7.0$. The activity was measured at $60^{\circ} \mathrm{C}$. 


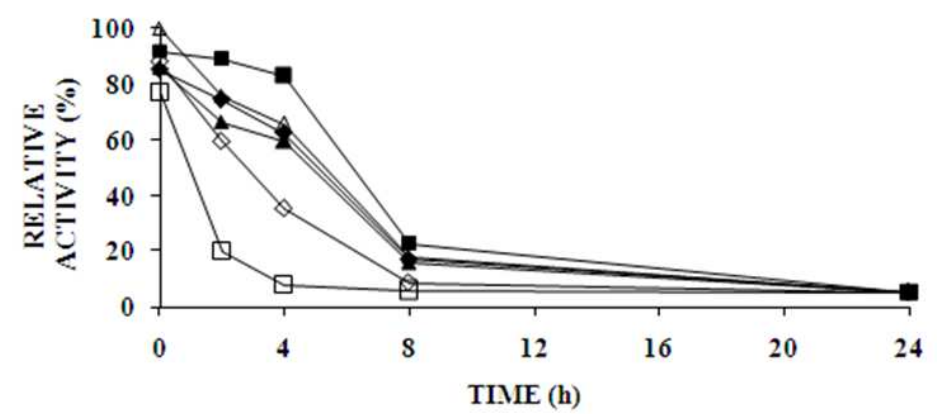

Figure 4b - Stability of the partially purified glucoamylase with respect to the pH: $\boldsymbol{\Delta} 3.6,4.0, \Delta$ $4.6, \square 5.0, \diamond 6.0, \square 7.0$. The activity was measured at $60^{\circ} \mathrm{C}$.

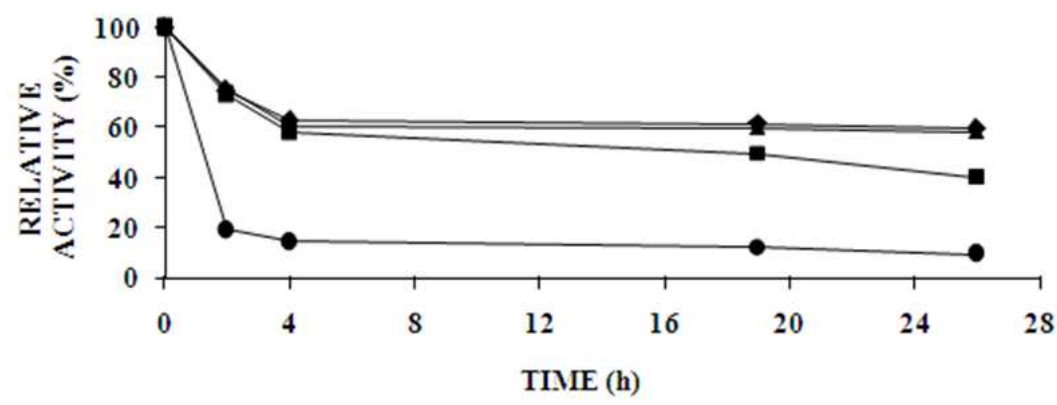

Figure 4c - Stability of glucoamylase (crude extract) with respect to the temperature : $\mathbf{- 1} 15^{\circ} \mathrm{C}, \boldsymbol{\Delta}$ $35^{\circ} \mathrm{C}, 60^{\circ} \mathrm{C}$ and $\bullet 70^{\circ} \mathrm{C}$. The residual activity was measured at $60^{\circ} \mathrm{C}$ and $\mathrm{pH} 4.6$.

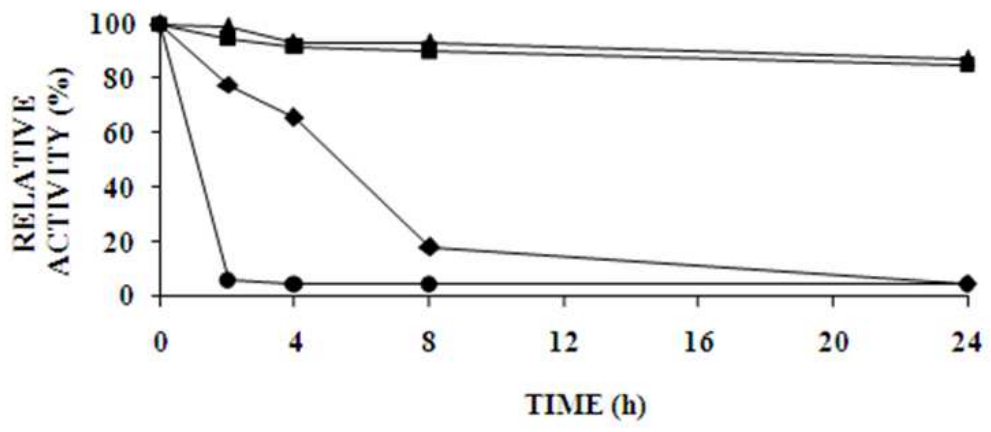

Figure 4d - Stability of the partially purified glucoamylase with respect to the temperature: - 15 ${ }^{\circ} \mathrm{C}, \Delta 35^{\circ} \mathrm{C},-60{ }^{\circ} \mathrm{C}$ and $\bullet 70^{\circ} \mathrm{C}$. The residual activity was measured at $60{ }^{\circ} \mathrm{C}$ and $\mathrm{pH} 4.6$.

Determination of the kinetic parameters $\left(K_{M} \mathrm{e}\right.$ $V_{\text {max }}$ )

The $K_{M}$ and $V_{\max }$ values calculated from the HanesWoolf plot for the partially purified glucoamylase were $0.34 \mathrm{mg} \mathrm{mL} \mathrm{m}^{-1}$ and $160.22 \mathrm{U} \mathrm{mL}^{-1}$, respectively, using soluble starch as substrate (Fig. $5 a$ and $5 b)$. 

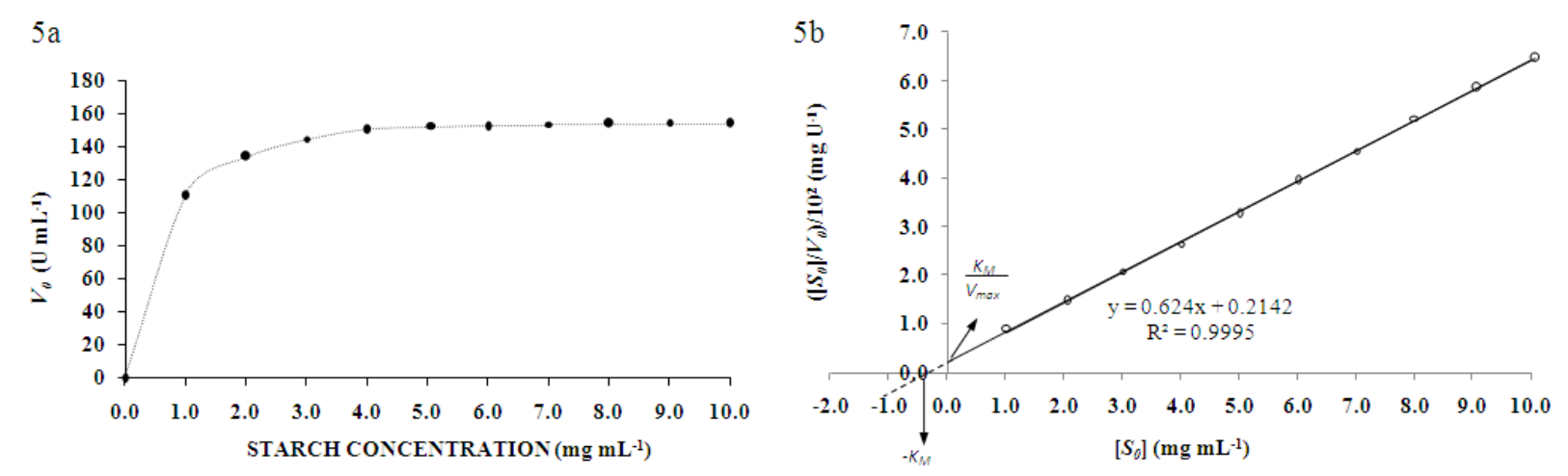

Figure 5a $-V_{0}$ values for the partially purified glucoamylase. 5b. Hanes-Woolf plot for the partially purified glucoamylase.

The potato processing residue contains large amount of starch, especially when the dry mass is considered (from the $15.34 \%$ of dry mass, starch corresponded to $12.56 \%$ ). This makes this residue an excellent carbon source, besides a starch source, for the amylase synthesis. Pandey et al. (1999) and Gupta et al. (2003) have reported the need of a starch source to induce the amylase production by fungi, yeast and bacteria. These microorganisms cannot assimilate complex molecules such as starch in native form, thus, they start to synthesize specific enzymes to transform the complex substrate into simple molecules, which assures the microorganism growth and development. According to Badino et al. (1999), starch hydrolysis into glucose is faster than the microorganism glucose consumption, which causes the growth inhibition and the enzyme synthesis repression due to the accumulation of the reaction product. Therefore, the absence of glucose in the residue is an extremely important factor to induce the glucoamylase synthesis.

For an industrial application of glucoamylase, it is important to take into consideration the optimal conditions for the enzyme action and stability. The results from the factorial design showed that the optimum temperature was around $60{ }^{\circ} \mathrm{C}$ while the optimum $\mathrm{pH}$ was 4.5-5.0 or even lower. This temperature, associated with the acidic $\mathrm{pH}$ value is valuable for industrial applications, as these conditions reduce microbial contaminations.

According to Gomes et al. (2007), in the industrial processes to hydrolyze the starch, at the saccharification step, the system must have the $\mathrm{pH}$ between 4.2-5.0. Additionally, the enzymes need the material to be cooled to temperatures below 60 ${ }^{\circ} \mathrm{C}$. The crude extract prepared during this work maintained more than $60 \%$ of the glucoamylase activity for more than $24 \mathrm{~h}$ when kept at $60^{\circ} \mathrm{C}$ and $\mathrm{pH}$ 4.6. These characteristics are satisfactory for the glucoamylase use in the starch processing industry during the saccharification step, which is carried out at exactly these optimal stability and activity conditions. Nevertheless, after the partial purification, the stability period decreased (not more than $25 \%$ activity remained after $8 \mathrm{~h}$ ), which disfavored the industrial use of the purified enzyme. On the other hand, when one intends to study the molecule physical chemical properties related to its action, a high degree of purification is mandatory.

The calculated molecular mass of $118.17 \mathrm{kDa}$ was higher than the reported for the glucoamylase I (91 $\mathrm{kDa}$ ) produced by $A$. niger (Aalbeek et al., 2002), the latter considered to be in native form, that is, without any proteolytic action, but quite similar to the one $(112 \mathrm{kDa})$ reported for glucoamylase II produced by the same organism by Pazur and Kleppe (1971). This could be an important information for a future work on the structure determination of a non-cleaved enzyme (Aleshin et al., 1994).

\section{ACKNOWLEDGEMENTS}

The authors thank CAPES and CNPq for the financial support and Dr. Tania Maria Bordin Bonfim (UFPR) for the microorganism supply. 


\section{REFERENCES}

Aalbaek, T.; Reeslev, M.; Jensen, B. and Eriksen, S.H. (2002). Acid protease and formation of multiple forms of glucoamylase in batch and continuous cultures of Aspergillus niger. Enzyme Microb. Technol., 30, 410-415.

Aiyer, P. (2005). Amylases and their applications. Afr. J. Biotechnol., 4, 1525-1529.

Aleshin, A.E.; Hoffman, C.; Firsov, L.M. and Honzatko, R.B. (1994). Refined crystal structures of glucoamylase from Aspergillus awamori var. X100. J. Mol. Biol., 238, 575-591.

Badino, A.C.; Facciotti, M.C.R. and Schmidell, W. (1999). Estimation of the rheology of glucoamylase fermentation broth from the biomass concentration and shear conditions. Biotechnol. Tech., 13, 723-726.

Buchholz, K. and Seibel, J. (2008). Industrial carbohydrate biotransformation. Carbohydr.Res., 343, 1966-1979.

Couto, S.R. and Sanromán, M.A. (2006). Application of solid-state fermentation to food industry: a review. $J$. Food Eng., 76, 291-302.

Dahlqvist, A. (1961). Determination of maltase and isomaltase activities with a glucose-oxidase reagent. Biochem. J., 80, 547-551.

De Vit, M.J.; Waddle, J.A. and Johnston, M. (1997) Regulated nuclear translocation of the Mig1 glucose repressor. Mol. Biol. Cell, 8, 1603-1618.

Gomes, E.; Guez, M.A.U.; Martin, N. and Silva, R. (2007). Thermostable enzymes: sources, production and industrial application. Quim. Nova, 30, 136-145.

Gouka, R.J.; Punt, P.J. and Van Den Hondel, C.A.M.J.J. (1997). Efficient production of secreted proteins by Aspergillus: progress, limitations and prospects. Appl. Microbiol. Biotechnol., 47, 1-11.

Griggs, D.W. and Johnston, M. (1991) Regulated expression of the GALA activator gene in yeast provides a sensitive genetic switch for glucose repression. Proc. Natl. Acad. Sci., 88, 8597-8601.

Gupta, R.; Mohapatra, H.; Goswami, V.K. and Chauhan, B. (2003). Microbial $\alpha$ - amylases: a biotechnological perspective. Process Biochem., 38,: 1599-1616.

Guzmán-Maldonado, H. and Parede-Lópes, O. (1995). Amylolytic enzymes and products derived from starch: a review. Crit. Rev. Food Sci. Nutr., 35, 373403.

Hanes, C.S. (1932). Studies on plant amylases: The effect of starch concentration upon the velocity of hydrolysis by the amylase of germinated barley. Biochem. J., 26, 1406-1421.

$\mathrm{Hu}, \mathrm{Z}$; Nehlin, J.O.; Ronne, H. and Michels, C.A. (1995), MIG1-dependent and MIG1-independent glucose regulation of $M A L$ gene expression in Saccharomyces cerevisiae. Curr. Genet., 28, 258266.
Keleher, C.A.; Redd, M.J.; Schultz, J.; Carlson, M. and Johnson, A. (1992), Ssn6-Tup1 is a general repressor of transcription in yeast. Cell, 68, 709-719.

Kim, T.S.; Lee, S.B. and Kang, H.S. (2004). Glucose repression of STA1 expression is mediated by the Ngr1 e Sfl1 repressors and the Srb8-11 complex. Mol. Cell. Biol., 24, 7695-7706.

Koutinas, A.A.; Wang, R. and Webb, C. (2003). Estimation of fungal growth in complex, heterogeneous culture. Biochem. Eng. J., 14, 93-100.

Laemmli, U.K. (1970). Cleavage of structural proteins during the assembly of the head of bacteriophage T4. Nature, 227, 680-685.

Lowry, O.H.; Rosebrough, N.J.; Farr, A.L. and Randall, R.J. (1951). Protein measurement with the folinphenol reagents. J. Biol. Chem., 193, 265-275.

Norouzian, D.; Akbarzadeh, A.; Scharer, J.M. and Moo-Young, M. (2006). Fungal glucoamilases. Biotechnol. Adv., 24, 80-85.

Pandey, A.; Selvakumar, P.; Soccol, C.R. and Nigam, P. (1999). Solid-state fermentation for the production of industrial enzymes. Curr. Sci., 77, 149-162.

Park, S.H.; Koh, S.S.; Chun, J.H.; Hwang, H.J. and Kang, H.S. (1999), Nrg1 is a transcriptional repressor for glucose repression of STAl gene expression in Saccharomyces cerevisiae. Mol. Biol. Cell, 19, 20442050.

Pazur, J.H. and Kleppe, K. (1971). Glucoamylase structure and properties of the two form so of glucoamylase from Aspergillus niger. Carbohydr. Res., 20, 83-96.

Rajoka, M. and Yasmeen, A. (2005). Induction, and production studies of a novel glucoamylase of Aspergillus niger. World J. Microbiol. Biotechnol., 21, 179-187.

Selvakumar, P.; Ashakumary, L. and Pandey, A. (1996). Microbial synthesis of starch saccharifying enzyme in solid state fermentation. J. Sci. Ind. Res., 55, 443-449.

Silva, R.N.; Asquieri, E.R. and Fernandes, K.F. (2005). Immobilization of Aspergillus niger glucoamylase onto a polyaniline polymer. Process Biochem., 40, 1155-1159.

Spier, M.R.; Woiciechowski, A.L.; Vandenbergue, L. and Soccol, C.R. (2006). Production and characterization of amylases by Aspergillus niger under solid state fermentation using agro industrials products. Int. J. Food Eng., 2, 1-19.

Treitel, M.A. and Carlson, M. (1995), Repression by SSN6-TUP1 is directed by MIG1, a repressor/activator protein. Proc. Nat. Acad. Sci., 92, 3132-3136. 